\title{
The Political is Personal: An Analysis of Crowd-Sourced Political Ideas and Images from a Massive Open Online Course
}

Mathew Humphrey

School of Politics and International Relations, University of Nottingham, Nottingham, UK.

Maiken Umbach

Department of History, University of Nottingham, Nottingham, UK.

Zeynep Clulow

Department of Politics and International Studies, University of Warwick, UK.

\begin{abstract}
The analysis of ideology at the vernacular level requires access to peer-to-peer political discussions amongst non-specialists. It is in these discursive exchanges that political views are articulated, refined, and revised. Such exchanges are, however, difficult for the researcher to capture. Here we take c.25,000 learner comments (along with several hundred image uploads) from a Massive Open Online Course, run in conjunction between the University of Nottingham and the British Library, as a source of such peer-to-peer political discussions. Learners discussed five topics, of which we have selected 'Freedom', 'Justice', and 'Community' for close analysis. We find that the idea of 'freedom' generated by far the most learner discourse, and in both the comments and image uploads this concept was both positively appraised and highly personalised. 'Justice' was generally seen as something to be delivered by political institutions, although accounts of injustice were frequently appraised through either personal experience or the experiences of others. Accounts of 'community' often focused on the trappings of nationhood, but some comments, and many images in particular, highlighted moments of ephemeral and more personal, self-chosen communities such as music concerts or hobbyist conventions. Overall, both comments and images show that, in their interpretation of the conceptual vocabulary of politics, people frequently frame their understanding through personal experience in a very direct manner. It is not only true that the 'personal is political', but also, for many, that the 'political is personal'.
\end{abstract}

\section{Introduction}

\section{So freedom for all is not possible without politics, but nor is complete freedom possible with politics $^{1}$}

The quote above is from a text in political thought. It is not however, a conventional work of political theory, but rather a comment from a learner on a 'massive open online course' (MOOC) on Propaganda and Ideology in Everyday Life, written in 2015. Analysis of the political views of 'ordinary' citizens, taken as complexes of ideas rather than as 'attitudes' or 'opinions' that can be assessed by survey questions, are relatively rare. This is in part because such ideas are often developed conversationally or argumentatively, in interaction with peers. Such conversations are, however, difficult for the researcher to capture as they will often take place in a private or semi-private sphere, and much of their complexity is lost if reduced to answers to opinion polls and surveys. Our suggestion here is that the many thousand learner comments generated by the 2015 run of this MOOC constitute a good digital proxy for just such 
a conversation between 'ordinary' people about political matters, providing valuable data for understanding political ideas at an everyday level.

Propaganda and Ideology in Everyday Life was co-produced by the authors and the British Library. The course, which is now delivered annually, is structured around five key themes: freedom, justice, community, place and belonging, and consumption and choice. Twenty five 'learning steps', each prompted by a short video or reading, explore the propagandistic and ideological significance of each of these ideas across a range of political contexts and historical periods, and each step involves intensive discussions amongst the participants. The first iteration of this course ran in May/June 2015. The following analysis is based on the overall experience of participant interactions, as well as more detailed statistical analysis of the comments posted in the first iteration of 2015, which recruited 12,394 'joiners' from over 20 countries. Of these participants, 3,881 were 'active', (completing at least some learning steps), and 1,585 were 'social learners', posting comments in the learner discussions, and uploading images of how they personally envisaged each one of our key political concepts. These social learners generated 24,871 comments, and contributed over 1,000 images in total. ${ }^{2}$ The discussions are moderated, but less than $1 \%$ of comments were deleted (due to use of offensive language). Participants responded to the learning materials for that week, to comments from the educators, and, in the vast majority of cases, to the comments by other participants. Their images were uploaded to a flickr site developed specifically for that purpose.

These comments constitute no 'typical' sample of public opinion: they are not statistically representative of the wider population of the United Kingdom, nor any other country or population group. The participants in our MOOC are also self-selecting, motivated to join by an interest in political ideas and ideologies. But they were almost all non-specialists, i.e. people with a personal interest in politics; as far as we can ascertain from the learner profiles, there were very few academics, practicing politicians, or professional journalists on the course. ${ }^{3}$ The comments emerged in and through a situation that is not unlike the situation in which most non-specialists articulate political ideas in everyday life: in conversation with others, or in response to 'expert' views they encounter through the media. As educators, we shaped the content of the course, and to some extent we 'got back' reflections on the material that we chose to expose learners to in the first place. However, while we were speaking to learners as academic educators rather than journalists or politicians, the motivation for participants to tack toward the views of the educators was minimal: as one participant wrote, unlike regular students, participants in the MOOC have no incentives to tell instructors what they think we want to hear. There is no assessment on this course, and the vast majority of participants' comments or images were made as part of peer-to-peer interaction amongst learners themselves. What makes them particularly interesting, and different from one-off comments made on other social media, is the sustained nature of the conversation through which they were generated: not as a singular expression of a view or preference, but as part of a discursive working-through of certain ideas, and reflection on how they 
relate to one's own particular political and cultural experiences, as well as those of others. Because of this, these contributions offer unique insights into how key political ideas such as justice, community, and freedom are expressed and imagined outside the confines of professional politics or professional political thought.

Before we proceed to our comparison, we should briefly outline our methodology. We posed two principal research questions. First, what specific conceptions of freedom, justice, and community were articulated by the participants on the 'Propaganda and Ideology' MOOC? Second, what other political ideas were most closely associated (either positively, negatively, or neutrally) with these conceptions? In answering these questions, we take a 'political idea' to be a distinctive concept that relates to a category or class of potential objects. So, for example, only some types of object, such as power relationships in a particular context, could be described as 'just' or 'unjust'; 'community' requires as its object a particular social group, which can exist in physical or virtual spaces (or both).

The analysis presented in this paper is qualitative, and dependent upon the manual reading of comments. However, in order to orientate the study, we fed all participant comments from the 2015 run of the course into Yoshikoder. ${ }^{4}$ Through this programme, we searched for word patterns and synonyms indicative of the relevant ideas. This formed the basis of a concordance report which retrieved passages of forty words (twenty on each side) surrounding the word occurrence. These passages were then read manually to identify key themes, issues and other words that were emphasised alongside each idea. These formed the basis of further dictionaries, which were applied back to the concordance results of the initial word searches to identify relevant trends and salience. Thus, we were able to put anecdotal impressions formed during the course to the test, and underpin some of our impressions with a systematic analysis of all comments appearing in the concordance reports.

This is an important process for a data source such as learner comments, as opposed to a more continuous document such as a political speech. For example, concepts are frequently present only because a previous comment is included in a reply, and in this way a single comment (and therefore a particular key word) can occur multiple times in a discussion thread. This can tell the researcher something useful, for example that a particular comment generated a vigorous discussion, but it can also render simple word-counts misleading. The results of this analysis reveal not just particular patterns in how political ideas are held, expressed and contested; they also uncover distinct differences between how particular political ideas are imagined.

\section{Political Ideas and Non-specialist Discourse}

In accordance with the discussion in the introduction to this special issue, we propose to study the political ideas expressed by ordinary people as a distinctive field, which is taken as an expression of the political agency of the individual contributors. Of course, all political texts, high-brow and 
popular alike, form part of the wider discursive field, and no author writes from a position of absolute autonomy, nor wholly controls the meaning of a text. In practice, however, great thinkers are still routinely credited with agency and originality, while it is assumed that 'popular' political thinking follows an essentially collective and derivative dynamic. It is time to test this assumption, and explore the nature of individual voices within everyday political thought.

Such an exploration raises interesting questions about the nature of the sources. Historians trying to uncover the political thinking of ordinary people in the past have often turned to so-called 'ego-documents', such as diaries and personal letters, in order to glean how and why individuals articulate or deploy political ideas. ${ }^{5}$ This has generated important new insights about how such political ideas were intertwined with their social aspirations, personal desires and anxieties, and spiritual longings. And yet, historians who have used such ego-documents, such as Stargardt and Duggan, ${ }^{6}$ have also been criticised for not reflecting sufficiently on the selection bias that lies in the nature of egodocuments itself. ${ }^{7}$ Keeping detailed diaries was a habit most typically found amongst educated middle classes. Particular religious traditions, too, such as Pietism, which place spiritual emphasis on continuous moral introspection, can similarly generate much richer ego-documents than more secular milieus. Another selection bias arises from the fact that people who align themselves with a particular regime or hegemonic ideology tend to reflect on politics more explicitly in their own life writing than those who maintained a sceptical distance, or rejected the official politics of the day. This problem is particularly acute in the study of ego-documents produced by 'perpetrators'.

Ego-documents are, then, worthwhile but limited sources for exploring questions about the relationship between the personal and the political. One thing they rarely capture is that ordinary people, like philosophers, tend to articulate political ideas in conversation and argument with others, rather than in introspective isolation. Diaries are by definition focused on individual experience, and tend to comment on politics only when this directly intrudes into personal life, for example, when soldiers are called up to fight on behalf of their country. Such exceptional circumstances aside, many egodocuments make few explicitly political statements. But this does not mean their authors held no such ideas. Instead of writing them in their diaries, however, they may have articulated these in conversation: with friends and family at the dinner table, in the pub, or when reacting to media prompts. As Chares Taylor has argued in relation to identity:

We are expected to develop our own opinions, outlook, stances to things, to a considerable degree through solitary reflection. But this is not how things work with important issues, such as the definition of our identity. We define this always in dialogue with, sometimes in struggle against, the identities our significant others want to recognise in us. ${ }^{9}$

We suggest that this is true of individual political beliefs more broadly; they are forged in the heat of dialogue. To grasp the formation of ideas in such conversations, we need sources that are simultaneously personal, and conversational. The learner comments on Ideology and Propaganda in Everyday Life possess these conversational characteristics. 
The five political ideas at the heart of our course share several important characteristics: all are invoked across a wide range of ideological milieus, and all are nearly always positively appraised. Very few people overtly oppose freedom, justice, belonging to a place or community. ${ }^{10}$ Yet despite the generally positive appeal of these concepts, people interpret them in very distinctive ways. This is true for private individuals as much as for formal political movements and theories. A communist vision of, say, freedom or community, differs radically from a fascist vision of freedom or community, or a liberal-capitalist one. Even within particular political milieus, these ideas are imagined differently: freedom and justice mean something different to liberals and conservatives operating within the same polity, and sharing the same commitment to basic constitutional principles. Within liberalism, too, we can find different understandings of these ideas, e.g. between neo-liberals, classical liberals, and progressive liberals. In these ways, our five political ideas are structurally similar, in that they are, to use Freeden's term, 'essentially contested'. ${ }^{11}$ They therefore provide an interesting starting point for understanding the political ideas held by ordinary people: they are not, on the whole, either/or choices, but questions of nuanced definition and interpretation, which in turn are negotiated in conversations. Moreover, these are also all ideas with strong roots in everyday culture. They relate not only to abstract questions of constitutional arrangements or economic structures, but reach deeply into more quotidian experiences, values, and feelings. Freedom, justice, territory, community, and consumer choices all featured prominently, for example, in recent debates around the British referendum, but they were put to notably varied uses, not just by Leave and Remain campaigners, but also within each of these camps.

For the purposes of this article, we focus on three of these concepts: freedom, justice, and community. In exploring how our participants understand and use these political ideas, we have drawn on the lens of conceptual morphology. ${ }^{12}$ For us, the decisive question was not just whether an idea such as freedom matters to people, but how important it is vis-à-vis other ideas, such as cultural inclusivity or social cohesion. Moreover, we are interested in how a particular idea of freedom is shaped by the way it is associated with adjacent concepts, or sub-categories. Defining freedom as a political idea always involves association with other concepts, such as the freedom of movement, or the freedom of trade; other conceptions of the same idea emphasise the absence of particular constraints, such as freedom from state interference, or, as was frequently emphasised in the context of the Brexit campaign, freedom from the culturally alien tutelage of supra-national institutions, such as 'Brussels', or from the perceived power of multi-national interest groups and lobbies. Similarly, justice can be understood as justice for the perceived interests of ordinary fellow citizens, who pay the price for the human costs of globalisation, or justice can be demanded on behalf of vulnerable human beings, such as refugees or asylum seekers, who may be fleeing, at least in part, from the consequences of the foreign policy of the countries in which they seek refuge. Community, too, can be inflected differently in comparable ways.

In addition to the question of how ideas are situated in ideological morphologies, however, we particularly wanted to find out how these political ideas are imagined in relation to the lived experience 
of those who see themselves as separate from, or even opposed to, the formal world of politics. These differences are thrown into sharp relief by the differing patterns that emerged from our evidence specifically regarding the three ideas of freedom, justice, and community. These differences, we shall argue, contain vital clues for understanding the role of individual voices in the formation of political value systems, and for the ways in which some ideas lend themselves much better to an understanding of politics that draws inspiration and authority from a notion of real-life, or 'authentic', experience. ${ }^{13}$

\section{Freedom}

The idea of freedom generated intense debate in both our course runs, more so than any other topic. In the 24,871 comments posted 'freedom' was employed 9,056 times and 'liberty' (which we take as a synonym) 1,043 times. In contrast 'justice' occurred on 1,217 occasions and 'community' 1,785. ${ }^{14}$ Amongst all these comments, we encountered none in which freedom was not positively appraised. Yet freedom as an idea, and ideal, meant many different things to different participants.

Broadly speaking, participants articulated variations on the conceptual themes of both 'negative' and 'positive' freedom. ${ }^{15}$ Many prioritised freedom from constraints. They expressed concerns about the state intruding into their personal sphere, especially through digital media, but also cited manipulations by commercial actors, such as the power of subliminal advertising, as subtly but crucially undermining freedom for modern citizens (see for example the comment below on smoking). A smaller body of comments identified the 'nanny state', intrusive regulations or high taxation, as undue constraints on a free life (one learner raised the example of legislation against home schooling in Germany). This 'negative' idea of freedom, defined as the abolition of, or overcoming of, external limitations to freedom, dominated discussions.

Some participants, however, explained their idea of freedom in terms more closely aligned with what we could classify as a 'positive' conception, that is, the freedom as possessing the power or resources to act in certain ways. Freedom, to them, was above all about empowering people through such policies as affirmative action. ${ }^{16}$ People who articulated this idea of freedom in terms of their personal experience were in the minority, and typically associated positive freedom with political activists of one sort or another. Some participants held that a positive idea of freedom had created the historical foundations of a political order that guaranteed the freedom from constraints they now enjoyed, or sought to protect. Several understood the present political system in many countries as being a result of a historical struggle, in which the quest for freedom was synonymous with the fight for sovereignty against foreign rulers or home-grown despots. ${ }^{17}$ Commonly cited examples were movements for national independence from colonial rule, as in India or Malaysia. ${ }^{18}$

We used our concordance results to assess participant comments in terms of whether freedom was taken to be threatened or constrained by internal factors (such as lack of rationality) or external 
factors (such as state interference). ${ }^{19}$ Around twice as many participant comments referred to external barriers to freedom as opposed to internal barriers. In many comments, a correlation was made between lack of freedom and economic inequality. The most frequently cited cause of lack of freedom was the restriction of economic opportunities for those at the lower end of the income distribution scale. ${ }^{20}$ The second most cited cause of unfreedom can be grouped under the heading 'society', in other words, the existence of social norms, and potential social sanctions, that militate against free expression of selfhood. ${ }^{21}$

When discussing internal barriers to freedom, participants tended to focus on the question of what it means to make a choice for oneself, what it entails to make a rational, autonomous decision free from extraneous (but not necessarily external) factors. One typical comment was made in reference to smoking:

Have to comment on the analogy with smoking which to my mind left out the power of the tobacco industry that did not give information that allowed the 'smoker' to make a rational decision/ fight his addiction for many years. Therefore the power of corporations and advertising subverted the freedom of choice of millions - without retribution - this power structure is also supported by governments happily collecting taxes for a lethal product.

This comment combines both external barriers to freedom (the power of large corporations and government to limit information) and internal barriers (smokers being unable to make a rational choice from their position of ignorance). Ideology itself also featured in comments as a barrier to making a truly free choice, or in constraining the capacity of individuals to think through ideas 'freely'. Participants frequently alluded to social conditioning, which relates to how they conceived of ideology. Ideology was widely seen as being channelled through social and political institutions, such as capitalism, the education system, and the laws and regulations of a society. Significant disagreement remained, however, on the question of whether violence, either by individuals or states, was ever a legitimate means to attaining freedom.

Freedom generated more comments, and more intense discussion, than any other topic, suggesting that freedom was given a very high priority amongst all possible political ideals and aspirations by nearly all of those who participated in discussions. This ranking may in part be due to the fact that freedom was the topic of our first week, when many participants were most eager to introduce themselves and their own political ideas to others. Very few comments suggested that the idea of freedom unduly dominated our political value system, or that higher priorities ought to be accorded to other political ideas or ideals. A discussion about the role of freedom in Islamic societies was the most prominent occasion upon which people asked whether there might be any other goals for the attainment of which ideas of freedom might need to be modified, or even limited in some way, and this remained very much a minority view. 
While freedom as a political idea was almost universally supported, its invocations by professional politicians and political parties were not. Many participants pointed to abuses of the concept by political actors and institutions, who they believed had either 'hollowed out' its authentic content, or championed a narrowly self-interested version of freedom. ${ }^{22}$ These invocations were contrasted, implicitly and explicitly, with participants' own ideas of freedom. Unlike the instrumental rhetoric of freedom they opposed, participants typically defined their own stance by imagining freedom simultaneously as a political or societal project, and as a deeply personal quest and aspiration. Many comments emphasised that the personal striving for freedom was compatible with, and in fact strengthened and reinforced, a commitment to freedom for others. Constraints to personal freedom were frequently seen as applying to whole communities, e.g. on grounds of ethnic discrimination or economic disadvantage; more rarely, gender norms were referenced as constraining the freedom of women. Indeed equality was the substantive concept most frequently used in concordance with freedom, in comments such as the following:

It is amazing to think that only a century ago women were excluded from much of what was supposedly a liberal and democratic society. Women were fighting for freedom and there can be no freedom without equality.

In opposing such constraints, political aspirations for freedom were frequently imagined as extensions of personal sentiment, and standing up for the freedom of others was grounded in an imagined similarity of personal experiences.

This points us toward an important finding about the nature of political ideas articulated outside the sphere of institutionalised politics. It appears that a political idea gains particularly widespread support, and a high priority status vis-a-vis other ideas, when it is imagined, experienced and grounded in deeply held individual aspirations and values. This finding is reinforced by the crowd-sourced images from our MOOC. At the end of the first week, we asked all participants to upload an image of what represented freedom to them - an exercise we repeated at the end of each subsequent week on the other core ideological concepts we discussed.

The idea of freedom solicited more images than any other concept. Exact quantification is complicated by two facts. First, because of the constraints of the FutureLearn platform on which our MOOC was hosted, the image uploads had to be hosted on a separate Flickr site; on this, we sourced about 650 images in the first run of the course, which were a combination of personal photographs (or more rarely drawings), and images sourced elsewhere, e.g. on the internet or in newspapers. In addition to these 650 images, a large number of learners posted written comments that included links to images already on another online platform, usually a website, but some of these contained more than one image, and several learners agreed that the same link or image best represented their personal imagination of the idea in question. Numbers, thus, can only give rough approximations of the nature of the discussion, but it is noteworthy that 'freedom', and what turned out to be a closely associated idea of 'nature', 
generated 401 individually uploaded images, and a comparable number of additional links, whilst the two themes of community and justice together only generated 223 individually uploaded images, plus a comparable number of links.

In terms of content, it was striking that most images of freedom had an intensely personal quality. Some were photos of participants themselves in a site or situation that embodied their quest for freedom; others, typically downloaded from the internet, showed anonymous individuals enjoying an experience of freedom in similarly personal ways: in nature, on mountains, flying in hang gliders, and so forth. They also included a very significant proportion of images of animals in natural setting, most popular amongst these images of eagles soaring in the sky, and one image of a captive eagle being released back into the wild. Such images express a deeply emotive and personal idea of freedom - but they are not a-political. In fact, many of the scenarios depicted find direct equivalents in what we might classify as propaganda images, or more neutrally put, images that are intentionally and professionally designed and deployed to produce, reinforce, or legitimate particular political behaviours and allegiances, whether by a political party, or for commercial purposes. One participant uploaded an image of the heraldic American eagle as the embodiment of freedom. The many images of wild eagles and other majestic birds uploaded by others may not explicitly reference the political icon, but they subtly echo this heraldic tradition.

Another link to more formal political iconographies relates to the perspectives employed in the freedom images. Many images featured landscapes viewed from a raised standpoint, such as a mountain top or a cliff by the sea, celebrating the gaze into wide-open, often untamed, 'wild' landscapes, as the sphere of true freedom. Iconographic traditions for such a gaze range from German Romantic paintings from the time of the 'Wars of Liberation' against Napoleon, to the imagery of the American frontier. ${ }^{23}$ But while these traditions have undoubtedly influenced the popular imagination of freedom, they are no longer perceived as tied to a particular political moment or location. In other words, the iconography has become so naturalised that people reproduce it in ways that express, to them, an experience that is unmediated, authentic, and devoid of manipulation by specific political actors or interests.

This is not to say that our participants thought of themselves as free. Many used this opportunity to upload an image of the kind of freedom to which they aspired, longed for, and, as their accompanying comments revealed, often felt they were denied in their daily lives. Nature was a favourite locus for such images because it offers, many participants argued, an escape from a world which is mostly unfree, due to political interference, economic pressures, or social norms. Freedom, for most, remained an aspiration - but an aspiration that is immediately accessible through emotion and experience. This, in turn, enables an appropriation even of formal political representations of freedom, such as the Statue of Liberty, into this vernacular pictorial imagination. The Statue, which was most frequently depicted in photographs taken from a distance, and often against a golden sunset, speaks, seemingly authentically, to an emotional longing that is not corrupted or diminished by its attachment to a particular historical 
and ideological moment. The same was true for images of iconic freedom fighters, such as Nelson Mandela, which were the second major type of image uploaded under this heading. Images of Mandela, many participants commented, represent not just a moment in the history of South Africa, but rather, a universal symbol of the human struggle for freedom, as well as an inspirational and authentic leader of this struggle, whose significance transcends any specific political and geographical political context.

\section{Justice}

Our MOOC participants' contributions to their online dialogue made very close conceptual connections between justice, equality, and freedom. Justice as equality was construed in various different forms. Most participants focused on financial equality; examples were given about differences in life quality between socio-economic classes and ethnic groups, unequal pay for different types of jobs and also financial barriers to fair trial (e.g. the ability to pay for a solicitor). Justice was contrasted with injustice, and the latter was frequently discussed in quite emotive terms, even if most accepted that interpretations of what is just and unjust could legitimately differ among reasonable people.$^{24}$ Comments that linked justice and freedom often focused on the freedom to live without fear of physical coercion, implying that it is the job of the state to apply the law to protect freedom. ${ }^{25}$

Most of the comments about justice were situated within four broad categories: the legaljudicial system, political regimes (including the government and political parties), physical conflict (both its conduct and aftermath), and economic equality. An important element of the discussion around justice referred to the imposition of criminal law. Several participants commented on their experience of providing jury service or, less frequently, acting as witness, observer, or judge in the courtroom, which most appraised positively, as giving them a sense of having a personal stake in upholding the value of justice. Some participants, however, also cited personal experience that demonstrated the presence of injustice in the legal system. For example, some participants shared their insight into cases in which they felt the crime had not been adequately punished. Others had more faith in the ability of legal systems to enforce justice. For example, a former judge provided a detailed insight into the kinds of measures that are taken to ensure a just outcome in the courtroom.

Around a quarter of the comments on justice related to the conduct of physical conflict and enforcement of post-war justice. Several participants weighed the strengths and shortcomings of the Nuremburg trials (a topic for one of the films on the course). The aftermath of military interventions in Iraq and Syria were also frequently mentioned as more recent cases of injustice. ${ }^{26}$ Around a quarter of justice discussions referred to particular political regimes to highlight the presence or absence of justice. Out of these, several examples related to the justness of political elites' actions and party political goals (as expressed in manifestos and speeches) as well as the government's toleration of dissenting opinions 
and the opportunity for freedom of expression (including speech and protest). A popular theme in the justice discussion was corruption - in the government, judiciary, and workplace and how this is detrimental to the realization of justice. To take one example:

"Recent protests against governmental corruption in Brazil are based on the idea of an injustice that must be corrected: we pay huge taxes (those of us who are productive citizens) and don't see the money collected in taxes going to Health \& Education for the poor. This is an injustice, because we are responsible for those who are not included in the productive system and pay taxes to alleviate their situation or promote their inclusion, not to fund political campaigns meant to perpetuate people in power."

Generally discussions of injustice tended to focus on specific examples (such as the gender pay gap, the allocation of seats under first-past-the-post, or the fate of aboriginal communities in Australia), often related to personal experience, whereas for justice itself, there was a tendency to draw on more abstract categories such as equality and freedom - and sense of a personal stake in justice was much less pronounced than it had been in the discussion of freedom. These findings accord with the work that William Gamson did with focus groups of non-specialist citizens discussing political issues of the day. Here he finds that it is the presence of an injustice frame that can be related to personal experience, and which is likely to provide a potential link to political action. Of course a sense of injustice is set within a broader, if implicit, sense of what justice requires, but it is the sense of injustice that captures people's immediate moral attention. ${ }^{27}$

The images uploaded under the theme of justice were also less personal than those submitted under freedom. The majority reverted to conventional allegories, such as the figure of Justitia, with sword and scales, often associated with court buildings, and a significant proportion of these had a satirical twist, usually as plays on the allegorical blindness of Justice as a blindness to the social and political realities. In others, the scales of justice were distorted by undue influence, such as the power of big business versus ordinary people. A second popular category of images showed protest relating of particular causes that exposed alleged injustices, from Amnesty International to anti-racists or antislavery rallies. Some participants uploaded allegorical drawings, such as chained hands breaking free; others showed victims of injustice, such as the abused bodies of slaves. A large number of these images also featured words: they were photos of writing, on posters, graffiti, or citations from famous speeches.

In the comments as well as in the pictures, the majority defined justice in terms of the consequences of its absence: it is visible only where it is denied, and the act of invoking it is to beseech the state, or the international community, to intercede in a particular political or social scenario in order to restore justice. Justice, in other words, was not pictured as a personal aspiration. The state, or some other authority structure - even the football referee was mentioned here - needs to provide justice, and we can demand it from others. But justice was not something that participants tended to embrace as a personal aspiration in and of itself. 


\section{Community}

National identity was the dominant theme in participants' comments about community, and accounts for over a third of all comments on this idea.$^{28}$ But while the idea of community was almost universally positively appraised, the idea of the national community was seen by some as a dangerous, if pervasive, distortion, or at least a partial and sometimes partisan appropriation, of the underlying longing for community. Most comments on national community explored how it is naturalised in daily life, in core symbols of the nation such as the national language, flag, anthem, citizenship, or engendering a shared sense of belonging and patriotism, which for many participants was sincerely felt. Several also mentioned that these nation-based community feelings are intensified when the nation is involved a military conflict. National sports events (especially football matches) were also frequently mentioned as catalysts for a stronger, if temporary, sense of community.

Ethnic and religious groups comprised the second most dominant theme of discussion of community. Both ethnicity and religion were identified as important pillars of community because of their role in creating a sense of shared culture and belonging among group members. This sense of identity was seen as something that could be in tension with the policies of a state, especially where nations comprise diverse ethnic or linguistic groups. ${ }^{29}$ Several participants stated that cultural and religious celebrations play an important role in creating and sustaining communities. There were many references to shared norms, beliefs and ethical standards as the cornerstone of community. Comments in this category underlined the role of the family and schools in keeping the community alive by passing on its defining values. Participants also referred frequently to Benedict Anderson's concept of imagined communities and Michael Billig's Banal Nationalism (both the subject of presentations on the MOOC) and singled out the sense of belonging and subjective connection as the defining feature of community. ${ }^{30}$

Comments on imagination and community underlined the importance of intentional communitybuilding, including through urban planning and design, in influencing our sense of belonging. One participant commented on Cadbury's model village:

Thinking about Bournville in Birmingham, it was an ideology of how the Quakers saw how its workers should live. There wasn't any public houses or off-licences in Bournville, they wanted its residents and workers to live in a particular way, this is a form of propaganda. Urban planning is a powerful way of making us choose how to live within a type of community.

Several comments in this category referred to (and often criticized) the influence that national governments possess over communities through national education and the media. ${ }^{31}$ Several participants gave examples of these types of influence from their own countries; propaganda in the Soviet Union was also a focal point. Map-making and national borders also frequently featured as 
important influences over one's self-identification with a community. Only around 6\% of comments on community directly described specific sites or places that are inhabited or 'owned' by a community. However, several comments described a nation's boundaries as a sensitive and important dimension of community. Moreover, the protection of the national boundaries was emphasised by some as a precondition for the survival of post-colonial communities. A small number of participants referred to their experiences of living in cosmopolitan cities to draw attention to changes and challenges to traditional homogenous concepts of community. Some participants also shared their experiences of living in different countries and the effect of this on their sense of community.

Community, then, was widely acknowledged as an important political idea that shapes our sense of self and the way we relate to others. Yet unlike freedom, and more like justice, it was seen less as a personal aspiration than as a phenomenon inextricably linked with state power, which in turn could be either positively or negatively appraised, or both (i.e. depending on the nature of the government in question, and thus of changeable political value and legitimacy).

The participants' images crowd-sourced under this theme, however, reveal a contrasting conception of community. Official symbols of nationalism - such as flags, parliament buildings, national monuments or even iconic national figures - appeared only very rarely. Nationalism, at least in its official visual manifestations, seemed far removed from the participants' personal visions of community. While many acknowledged their familiarity with distinctive national iconographies (e.g. in the way particular places or historical moments were represented on picture postcards, in school textbooks or in children's fairy tales), few participants were ready to embrace such representations as embodying "their" own, personal imagination of community. Similarly, while many spoke about their experience of community on the local level, these featured rarely in uploaded images. A few participants shared images or maps of cities or neighbourhood they considered home. Some also shared images of the particular streets they had grown up in, but these were always associated with very particular stories, for example, if the neighbourhood in question had rallied around a particular cause, or against a particular threat.

Without such specific narratives attached to them, there seemed relatively little appetite for an emotional embrace of places that could be 'pictured'. What we did see was a proliferation of images depicting what we might call experiential, and ephemeral, communities. For many participants, the idea of community was best signified by photos of gatherings of people, usually outdoors, who had come together for a particular purpose, sometimes in market places, but more often in the context of leisure and celebration: the open air rock festival, the national bikers' get-together, a new age campsite. This adds an interesting dimension to the way in which the notion of community operates as a political idea in everyday life. It seems to fall broadly into two categories: on the one hand, the experience of community as an idea that is produced or shaped by political power, for better or worse; on the other 
hand, a more ephemeral lived experience of community, as people coming together around a shared set of habits or values, which was almost universally positively appraised.

It is tempting to dismiss this valorisation of ephemeral experiences of community as not properly political: it involves no notion of formal citizenship, and no participation in the exercise of power. And yet, it is important to take seriously such deeply held beliefs in alternative forms of community. Scholars have recently suggested that in a 'postmodern condition', chosen forms of identity, which are often related to particular sub-cultures of consumption, trump ascribed collective identities as defined by sociologists, marketers, or demographers. ${ }^{32}$ Membership is such communities is defined not by (more or less) immutable characteristics such as income, occupation, or place of residence, but through processes of what Schouten and McAlexander call 'self-authentication' through 'flow' activities. 'Flow' activities provide a sense of 'being in the moment', of engaging in the relevant activity in a way that provides the personalised benefits of it. Such activities offer a feeling of connectivity with an alternative form of imagined community, whose members are bound together by shared practices and experiences, which, in turn, reflect political values: particular forms of social interactions, but also, in many instances, a feeling of connection with nature, place, or with some ideal of right living. Tellingly, many of the rituals associated with such experiences of community draw on other values that participants expressed in other sections of the MOOC, most notably freedom, and the ability, through immersion in natural environments, to discover or re-capture a sense of natural selfhood.

\section{Conclusion: Personalising the Political?}

Part of the value of using sources generated by our Massive Open Online Course rests on its capacity to generate a dialogical conversation about its subject matter, in this case, clusters of political ideas, across an international and diverse group of learners. This online discussion parallels, to some extent at least, the face-to-face discussions in which most non-specialists would typically articulate their political ideas. As a framework for analysis, conceptual morphology directs our attention to two specific aspects of these learner discourses. Firstly, the conceptions of the concepts that learners are articulating. What do they take justice to consist in, for example? What is its scope? Who are the agents or recipients of justice? This is not always immediately obvious from any individual learner comment, but over several thousand iterations, a picture does begin to emerge, such as the tendency to see freedom in highly personalised terms. The second is, with what other political concepts is the concept under analysis, positively, negatively, or neutrally associated?

So for example, we see the association of justice with both equality and freedom, in roughly equal proportions. On the former element of our analysis, it is often claimed, by feminists and others, 
that 'the personal is political'33, while our analysis shows that for many people, it is also true that the political is personal, but only across some quite specific political domains. Freedom is conceived in highly personalistic terms, as something that people want to achieve for themselves across different conceptions of the concept. There is a recognition that collectives can be more or less free, as expressed in some commentaries on anti-colonial struggle, for example. However, in both comments and, especially, images, freedom is portrayed as the release of the individual from the constraints of politics and society. Likewise injustice is conceived in personalised terms - it is something visited upon identifiable people - oneself or others, and even when visited upon entire groups, certain individuals, such as Nelson Mandela or Martin Luther King Jr., can become emblematic of a broader struggle for justice. Other political concepts, such as justice or community, appear to be conceived in less personalised terms, or at least not so much in terms of individual aspirations, and more in terms of institutional and collective forms of political life. Our findings also suggest that for many participants, the concepts of freedom, justice, and equality sit in a mutually supportive relationship. ${ }^{34}$ Economic inequality was seen by most as a major impediment to freedom for those at the bottom of the income distribution, as the poor are denied life-chances that their better-off peers can take for granted. Furthermore, participants were as likely to associate justice with freedom as associate it with equality - justice was taken to be that which guarantees our freedom to make choices for ourselves.

A striking feature of the uploaded images was the fluidity with which they traverse specific countries and cultures. As we have seen, for many learners, the Statue of Liberty is an important icon of freedom; others replicate such official symbols in more mediated, and hence more personalised form: the eagle flying into the sunset is classic example. The nature of our data does not allow us to offer statistically precise correlations between the learners' respective nationalities and their choices of images, from self-identifying comments accompanying the images. Nonetheless, it seems clear that the use of such images of freedom was by no means confined to American participants: it is, instead, an iconography of near universal appeal. The same can be said of images that conjure up historical memories as embodiments of particular political value: Nelson Mandela and Martin Luther King were frequently chosen as representing a participant's idea of freedom (some used the same images as embodiments of justice), and their popularity did not appear to depend on the geographical base of the participants in question. The same geographical fluidity applies to quotations from famous political speeches, which were often uploaded as images, either just as pieces of typography, or occasionally as graffiti on public walls and buildings - but not necessarily in one's own neighbourhood or country. In part, these images simply document that modern digital media travel very easily around the world: more easily so, in fact, than the written word, although catchy quotations and mottoes seem more mobile than longer political texts. This use of such images also demonstrates, however, that the personal political imagination of our participants is much less confined by regional and national boundaries than suggested by the formal political discourse we might see in the news. Interestingly, values that are 
experienced in the most immediately personal and emotive ways are often associated with images drawn from a global pool of visual representations and memories. It seems that the more chronologically 'distant' a particular image is, the more easily it is appropriated into the political imaginations of individuals living today. That is not to say, of course, that the same image represents exactly the same thing in different countries: but neither does it represent exactly the same thing for two people who live in the same country but may be separated by class, gender, or formal political affiliations. Images appear to have a particular quality that allows an almost effortless re-cycling and re-coding, so they can be inserted into ways of thinking and feeling about the political that are experienced as deeply personal, and intensely of the moment.

Images of community, by contrast, were relatively more place-bound, although few of them represented communities fixed in place. The communities depicted, however, were typically of gatherings or communal events that people had experienced in person, or to which they had an immediate personal connection, say through friends or family. In the written comments, participants rarely made their definition of community explicit; few commented on whether joining a community was a fact of birth or an act of choice. But written comments did focus on the processes through which a belief in and political attachment to the idea of community comes about. This may reflect the fact that the participants in this course brought a pre-existing interest in propaganda and ideology to the discussion, which was, after all, the subject matter of the MOOC. For all that, the manner in which participants understand processes of community creation tells us something of how community is understood more widely. There was much reflection on the social mechanisms through which a sense of community is created: family, school, churches and other places of religious worship, and the symbols that accompany this process of creation. While expressing some critical distance from these processes, most participants did not believe that the idea of community was a bad thing; many credited it with creating social cohesion and transmitting values of co-operation and mutual trust.

While national communities featured frequently in the discussions, their symbols rarely featured in the images of what community 'meant' to individual leaners. When personalising an idea, or ideal, of community, participants focused particularly on voluntary and ephemeral communities, many of which are created through a sense of shared interests or commitments. On a personal level, it may mean much more to share a rock festival, a biking tour, or a hobby convention than to be a citizen of a particular country, in terms of the felt sense of community that one experiences. And while in one sense such ephemeral communities may seem a-political, not explicitly organised for political purposes, they may still depend on, and in turn engender or strengthen, other political principles, such as freedom of expression. This is not to tie the flourishing of such communities to liberal political culture - they may also be supported by populist regimes eager to draw on the emotive power of collective experience for purposes of political mobilisation. 
Our evidence constitutes a snapshot of the political ideas of a self-selecting group of nonspecialists; yet it does suggest some interesting avenues for further research. It may be that populations find discourses around justice and equality relatively distant and abstract, even if they also see these values as fundamentally important. Justice is a strongly held value, but not an individual aspiration: it ran be rendered politically effective if it is linked, both conceptually and viscerally, to a specific instance of injustice, real or perceived. That is why 'scapegoating' and conspiracy theories play such an important role in populist political discourse: if a sense of acute injustice can be linked to a specific actor or group of actor, the value loses its abstract quality, and motivates political action. ${ }^{35}$ If we are right in concluding that the idea of freedom is seen in more intensely personal terms, closely associated with the aspirations of individuals, it may be easier to make this idea resonate politically, without requiring the political status quo to be portrayed as a deceptive illusion. Even those who feel that they live in a relatively free society, and appreciate the political freedom that their state or social environment grants them are likely to hold a personal ambition to achieve a greater, emotionally more intense or authentic experience of freedom in their personal lives, and thus feel called upon to take action to realise the potential of freedom for themselves. Community, too, has aspirational resonances of this kind, but they are less pronounced than those of the idea of freedom, and more typically tied to specific temporal moments than to life narratives. 'Justice talk' often draws on broad, fairly abstract notions of equality or fairness, with only tentative connections to lived experience. 'Injustice' talk, by contrast, is frequently related to personal stories, which do not, however, translate into a conceptual aspiration in the same way that freedom does.

Such findings, in turn, may tell us something about why certain political frames have proved more effective than others in connecting to the ways in which 'ordinary' people understand and imagine political ideas. It is at least arguable that we saw evidence of this in the 2016 UK referendum on EU membership. A campaign based on themes of freedom ('take back control' from distant Eurocrats) and collective injustice (in that the UK pays more in than it gets out, and that money could be used for those in need in the UK) appears to have resonated more strongly than the alternative, which was based almost solely on the economic consequences of leaving. ${ }^{36}$ Similar points might be made about the effectiveness of the Trump campaign in the 2016 US presidential elections. ${ }^{37}$ These conclusions do not only apply to right-wing populism. Rather, they may suggest why political movements and parties of any ideological complexion that effectively frame their agendas in terms that speak to the nexus between the personal and the political gain more traction with voters than others. This is perhaps the most significant explanatory benefit to emerge from our analysis of the MOOC participants. The deep entanglement of personal sentiment, affect, and identity performance on the one hand, and formal political ideas and ideologies on the other, does of course have a long history. But it is an interface that is only likely to increase in significance in future, as digital platforms such as Facebook and Twitter energise and make visible the juncture between the personal and political dimensions of people's lives and experience in 
innovative and increasingly prevalent ways. This means that understanding exactly how 'the political is personal' will become ever more central to the analysis of politics in the world we inhabit 
${ }^{1}$ Learner comment (LC) 'Propaganda and Ideology in Everyday life', 2015.

${ }^{2}$ The MOOC is hosted by the FutureLearn platform. All learners who sign up for courses agree to the following: 'You consent that we and our Partners Institutions may conduct research studies that include anonymised data of your interactions with the Website, including Learner Content.'. FutureLearn, 'Terms and Conditions' https://about.futurelearn.com/terms/ (accessed $7^{\text {th }}$ March 2017).

${ }^{3}$ This is not unproblematic as we do not have systematic information on learner occupations. Learners are asked to introduce themselves in the first session and several, although not all, discuss their occupation. A selection includes an optometrist, several school teachers, a tourism professional, marketing manager, business consultant, and a lawyer. As with the overall demographic of FutureLearn learners, many of our participants had degree-level qualifications, several of which are in humanities and social sciences. As noted, we are not suggesting the profile of the learner community is representative of any broader population.

${ }^{4}$ yoshikoder.sourceforge.net/ (accessed 20/10/17).

${ }^{5}$ M. Fulbrook and U. Rublack, 'In Relation: The "Social Self” and Ego-documents', German History, 23(3) (2010), pp. 263-72

${ }^{6}$ N. Stargardt, The German War: A Nation Under Arms, 1939-45 (London: Random House, 2015); C. Duggan, Fascist Voices: An Intimate History of Mussolini's Italy (Oxford: Oxford University Press, 2013).

${ }^{7}$ For a critique of Stargardt in this vein, see R. J. Evans, 'Your Soft German Heart', London Review of Books, 38(14), 2014, pp.25-27.

${ }^{8}$ C. R. Browning, Ordinary Men: Reserve Police Battalion 101 and the Final Solution in Poland (New York: Harper Collins, 1992). D. J. Goldhagen, Hitler's Willing Executioners: Ordinary Germans and the Holocaust (New York: Vintage Books, 1997).

${ }^{9}$ C. Taylor, Charles, The Ethics of Authenticity (Cambridge MA: Harvard University Press, 1991), p.33.

${ }^{10}$ A partial exception is consumption and consumer choice, which can be more controversial: while many view the idea of choice as essentially positive, others have suggested that in practice, it is often illusory, obscuring the dominated by capitalist relations of production and consumption. Cf. H. Marcuse, One-Dimensional Man: Studies in the Ideology of Advanced Industrial Society (Boston: Beacon Press, 1964).

${ }^{11}$ M. Freeden, Ideologies and Political Theory: A Conceptual Approach (Oxford: Oxford University Press, 1996), who takes his inspiration from W. B. Gallie, 'Essentially Contested Concepts', Proceedings of the Aristotelian Society, 56 (1955), pp.167-198.

${ }^{12}$ Freeden, ibid.

${ }^{13}$ For a fuller discussion of authenticity's role in mediating between political concepts and lived experience, see M. Umbach and M. Humphrey, Authenticity: The Cultural History of a Political Concept (London: Palgrave, 2017).

${ }^{14}$ Each of these concepts had a week on the course devoted to it. Even granted the caveats noted above on word repetition in learner comments, this still makes 'freedom' the most frequently employed political idea by some margin.

${ }^{15}$ I. Berlin, Four Essays on Liberty (Oxford: Oxford University Press, 1971).

16 'Equality comes into the realisation of positive freedom when affirmative action is needed to support the disadvantaged' LC, 2015.

17 '[F]reedom is much more important than equality. So first you have to struggle for freedom' LC, 2015.

18 'During the colonial times we were eager to get freedom from the British rule' LC, 2015.

${ }^{19}$ Learners were introduced to the notions of 'positive' and 'negative' liberty through a discussion of the work of Berlin, op. cit. Ref. 15, and others. 
20 ‘[S]omeone raised in poverty might think freedom was just having enough to eat’ LC, 2015.

${ }^{21}$ For example 'Freedom from government is not absolute freedom provided social conventions still exist' (LC, 2015) - although others highlighted that such norms help to make societies governable.

${ }^{22}$ One example comment here: '[T] he suggestion from the DUP [Democratic Unionist Party] to have a "conscience clause" giving Christians the freedom to discriminate against gay people is an example of how politicians use words like "freedom" to suit their own agenda'. Another example: 'most of [our?] politicians now use Freedom to help themselves and their groups instead of other groups or people.' LC, 2015.

${ }^{23}$ W. Vaughan, K. Hartley, H. M. Hughes, and P-K. Schuster, The Romantic Spirit in German Art 1790-1990 (London: Thames \& Hudson, 1994); S. M. Heydt, N. M. Besaw, and E. I. Hansen, Art of the American Frontier: From the Buffalo Bill Center of the West (New Haven: Yale University Press, 2013).

${ }^{24}$ To take one example: 'I hate war, I hate injustice and I hate unfairness but who is to say what is just, is my justice somebody else's injustice?' LC, 2015.

25 'I believe the only way to be free is under the protection of justice'. LC, 2015.

26 '[R]ecent history shows that today, wars are waged that are neither morally justified (Iraq, Syria, Libya) or morally waged (Israel v Palestine)' LC, 2015.

${ }^{27}$ See W. A. Gamson, Talking Politics (Cambridge: Cambridge University Press, 1992).

28 ' [L]ots of people do want to feel connected with their neighbour and part of an identifiable community, and so national soverignity [sic] is what they will fight for.' LC, 2015.

29 'A good European example of how disastrous it can be to hold lots of ethnic minorities together artificially is Yugoslavia, look how that ended.’ LC, 2015.

${ }^{30}$ B. Anderson, Imagined Communities: Reflections on the Origin and Spread of Nationalism (London: Verso, 1983); M. Billig, Banal Nationalism (London: Sage, 1995).

31 'In the civilised world we have to fit into whatever community we inhabit from birth, socialised by our parents, family, other members of the community as well as religions, education systems, laws, and government.' LC, 2015.

${ }^{32}$ Schouten and McAlexander illustrate this with the short biography of a Mexican-American surfer: "His best friends, all surfers, never heard him speak or respond to a word of Spanish. When he married it was to a blonde 'surfer chick'. Chuck certainly belonged to a subculture, but not the one assigned to him by the U.S. census; he belonged to a subculture of consumption." J. W. Schouten and J. H. McAlexander, 'Subcultures of consumption: An ethnography of the new bikers', Journal of Consumer Research 22(1), (1995), pp. 43-61, p.59. On self-authentication, see also Umbach and Humphrey, op.cit. Ref, 13, chapter 5.

${ }^{33}$ C. Hanisch, 'The Personal is Political' Notes from the Second Year: Women's Liberation (1970) http://www.carolhanisch.org/CHwritings/PIP.html (accessed 20/10/17).

${ }^{34}$ For example, 'I do not believe we can discuss freedom and equality together without discussing justice' LC, 2015. Also 'How can there be freedom and justice without equality?' LC, 2015.

${ }^{35}$ The historical connection is teased out by P. Fritzsche, Rehearsals for Fascism: Populism and Political Mobilization in Weimar Germany (New York: Oxford University Press, 1990). A discussion of the same nexus in contemporary populism is C. Berlet, 'Taking Tea Parties Seriously: Corporate Globalization, Populism, and Resentment', Perspectives on Global Technology and Development, 10(1), (2011), pp. 11-29.

${ }^{36}$ On the EU referendum campaign, see T. Shipman, All Out War: the Full Story of How Brexit Sank Britain's Political Class (rev. ed.), (London: William Collins, 2017); C. Oliver, Unleashing Demons: the Inside Story of Brexit (upd. ed), (London: Hodder \& Stoughton, 2017).

${ }^{37}$ Tur, Katy Unbelievable: My Front-row Seat to the Craziest Campaign in American History (New York, HarperCollins, 2017). 